Економічні науки: збірник наукових праиь Луиького національного технічного університету. - Серія "Регіональна економіка". - Випуск 15 (59). - Редкол.: відп. ред. д.е.н., професор Л.Л. Ковальська. - Луцьк: ІВВ Луиького НТУ, 2018. - 292 с.

УДК:631.1:574:332.33

Коренюк П.І., д.е.н., професор

\title{
РОЛЬ ІННОВАЦІЙ У ЗАБЕЗПЕЧЕННІ ЕФЕКТИВНОГО РОЗВИТКУ АВТОМОБІЛЬНОЇ ПРОМИСЛОВОСТІ В УКРАÏHI: ПРАВОВІ АСПЕКТИ
}

У даній статті розглянута роль інновацій у забезпеченні ефективного розвитку автомобільної промисловості в Україні. Досліджено фактори та 
Економічні науки: збірник наукових праиь Луиького національного технічного університету. - Серія "Регіональна економіка". - Випуск 15 (59). - Редкол.: відп. ред. д.е.н., професор Л.Л. Ковальська. - Луцьк: ІВВ Луиького НТУ, 2018. - 292 с.

чинники інноваційного впливу на показники та обсяг виробництва автомобілів в Україні.

Ключові слова: промисловість, система управління, автомобільний транспорт, ефективність, інновації, удосконалення.

\section{Korenyuk P.}

\section{THE ROLE OF INNOVATIONS IN PROVIDING EFFICIENT DEVELOPMENT OF THE AUTOMOTIVE INDUSTRY IN UKRAINE: LEGAL ASPECTS}

The level of development of the automotive industry largely determines the level and pace of development of national machine building and the national economy as a whole. The Ukrainian automotive industry is experiencing far better times, but there is considerable potential and resources for its reincarnation and bringing it to a competitive level. . One of the factors of decent formation and restoration of the automotive industry is an innovative factor. Investments should be aimed not only at maintaining it at a certain level, but mainly they should be directed to a technological breakthrough in this area. As experience of the developed countries of the world shows, at the expense of innovation development of the automobile industry it is possible to significantly accelerate the economic development of the country as a whole. Investment and innovation activities are important for the automotive industry. By its very nature, the car is an innovative achievement, which focuses on the achievements of scientists from different industries and countries. The automotive industry in Ukraine is experiencing no better times. Currently, the automotive industry mainly includes car assembly companies. The reason is the economic background and the fact that domestic production of cars in full cycle remains less advantageous compared with the collection. At the present stage of development for the domestic automotive industry, an extremely important issue is to increase the share of attraction of foreign direct investment, since, apart from loans and loans, investments do not drive the state into a debt hole. Moreover, it is advisable to mark the innovative direction of the attracted investments. There is a need to adapt existing national legislation in the field of road transport to the European one, in particular regarding the management of transport, the regulation of the market of transport services, access to the market for passenger and cargo transportation services, enhancing the competitiveness of road carriers, ensuring traffic safety, transit transport, border control, definition of requirements for wheeled vehicles, transport statistics, environmental and social requirements. In addition, it is necessary to integrate the domestic road transport system into European through the association with the trans-European transport network in accordance with the European Neighborhood Policy.

Key words: industry, control system, automobile transport, efficiency, innovation, improvement 

університету. - Серія "Регіональна економіка". - Випуск 15 (59). - Редкол.: відп. ред. д.е.н., професор Л.Л. Ковальська. - Луиьк: ІВВ Луиького НТУ, 2018. - 292 с.

Коренюк П.И.

\section{РОЛЬ ИННОВАЦИЙ В ОБЕСПЕЧЕНИИ ЭФФЕКТИВНОГО РАЗВИТИЯ АВТОМОБИЛЬНОЙ ПРОМЫШЛЕННОСТИ В УКРАИНЕ: ПРАВОВЫЕ АСПЕКТЫ}

В этой статье исследована роль инноваций в обеспечении эффективного развития автомобильной промышленности в Украине. Исследованы факторы инновационного влияния на показатели и объем производства автомобилей в Украине.

Ключевые слова: промышленность, система управления, автомобильный транспорт, эффективность, иннновации, усовершенствование.

\section{Постановка проблеми у загальному вигляді та іï} зв' язок із важливими науковими та практичними завданнями. Місце $\mathrm{i}$ роль будь-якої країни у світогосподарському просторі певною мірою визначається відповідністю показників іiі соціально-еколого-економічного розвитку міжнародним стандартам. Рівень розвитку автомобільної промисловості багато в чому визначає рівень та темпи розвитку національного машинобудування і національної економіки в цілому. В сучасних умовах вступу України в СОТ ставлять показники конкурентоспроможності галузей національної економіки в один ряд 3 показниками економічної і національної безпеки. Українська автомобілебудівна галузь переживає далеко не кращі часи, але $є$ значний потенціал i ресурси для іiі реінкарнації і виведення на конкурентний рівень. Одним 3 чинників гідного становлення та відновлення автомобільної промисловості $\epsilon$ інноваційний чинник. Так, інвестиції дуже потрібні у вітчизняний автопром. Але, вони мають бути направленні не лише у підтримання його на певному рівні, але головним чином їх потрібно спрямувати на технологічний прорив у даній сфері. Потрібно досягти виробництва вітчизняного автомобіля, який буде конкурентоспроможним i при цьому матиме повний цикл виробництва в Україні. Інновації, як показує світовий досвід, сприяють вирішенню подібних завдань і їх роль має стати 
Економічні науки: збірник наукових праиь Луиького національного технічного університету. - Серія "Регіональна економіка". - Випуск 15 (59). - Редкол.: відп. ред. д.е.н., професор Л.Л. Ковальська. - Луцьк: ІВВ Луиького НТУ, 2018. - 292 с.

визначальною, а їх обсяги мають стати реальними, а не носити лише номінальний характер.

Аналіз останніх досліджень, у яких започатковано вирішення проблеми. Дослідженнями проблем ефективного розвитку підприємництва, зокрема екологічного, займались ряд таких вчених як В.В. Біркентале [6], В.П. Божко [3], Б.М. Данилишин [5], А.О. Зима [6], С.О. Матковський [8], О.В. Прокопенко [9], О.С. Семирак [10], С.В. Чорнобровкіна [11], I.А. Шеховцова [12] та інші видатні українські та закордонні науковці. Основні положення щодо інноваційної діяльності та формування сприятливого інноваційного поля відображені в Законі України про інноваційну діяльність [4] та знайшли подальший розвиток у Концепції розвитку автомобільної промисловості та регулювання ринку автомобілів у період до 2015 року [7].

Цілі статті. Метою даного дослідження у форматі наукової статті є 3'ясувати та визначити роль інновацій у забезпеченні розвитку підприємництва, зокрема екологічного.

Виклад основного матеріалу дослідження 3 обгрунтуванням отриманих наукових результатів. Автомобільний транспорт $є$ однією 3 найважливіших сфер підприємницької діяльності, оскільки у процесі господарювання кожна фірма потребує перевезення матеріалів, сировини, готової продукції, при цьому вони використовують власний автотранспорт або користуються послугами автотранспортних підприємств. Автомобільний транспорт відіграє важливу роль в соціально-економічному розвитку країни. На сьогодні більш як 100 тис. автомобільних перевізників надають послуги 3 перевезення $52 \%$ пасажирів та $64 \%$ вантажів. Автомобілебудування у загальній частині машинодування, зокрема транспортного, посідає вагоме місце (рис. 1). 
Економічні науки: збірник наукових праџь Луцького національного технічного університету. - Серія "Регіональна економіка". - Випуск 15 (59). - Редкол.: відп. ред. д.е.н., професор Л.Л. Ковальська. - Луцьк: ІВВ Луиького НТУ, 2018. - 292 с.

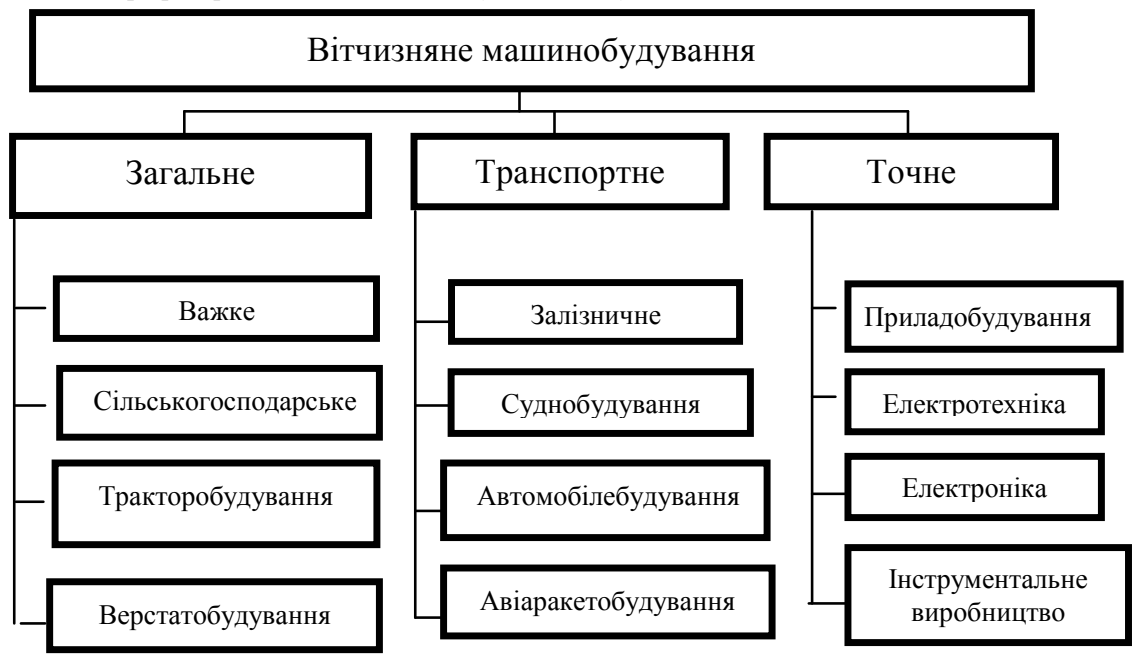

Рис. 1. Місце автомобілебудування у загальній структурі вітчизняного машинобудування

Вітчизняна автомобілебудівна промисловість є галуззю машинобудування, яка виробляє автомобілі, запасні частини, автомобільні двигуни, агрегати, причепи та напівпричепи. Автомобільний транспорт у цілому задовольняє потреби національної економіки та населення у перевезеннях, однак структура парку автобусів та вантажних автомобілів $\epsilon$ недосконалою, більшість транспортних засобів за своєю конструкцією, пасажиромісткістю, вантажністю, типами кузова, класом комфортності, видами та питомими витратами палива, екологічними показниками не відповідають сучасним вимогам.

Автомобільна галузь традиційно є пріоритетною для ряду країн світу. Стан розвитку автомобілебудування визначає і зараз ключові віхи та вектори розвитку ряду національних економік. Як показує досвід розвинутих країн світу, за рахунок інноваційного розвитку автомобільної промисловості можна відчутно прискорити економічний розвиток країни у цілому. У порівнянні з іншими країнами світу Україна відчутно відстає щодо забезпеченості легковими автомобілями (табл. 1). 
Економічні науки: збірник наукових праџь Луцького національного технічного університету. - Серія "Регіональна економіка". - Випуск 15 (59). - Редкол.: відп. ред. д.е.н., професор Л.Л. Ковальська. - Луцьк: ІВВ Луиького НТУ, 2018. - 292 с.

Таблиця 1

Кількість легкових автомобілів на 1000 осіб населення за 2016 рік, штук

\begin{tabular}{|l|c|c|c|}
\hline Країна & $\begin{array}{c}\text { Чисельність } \\
\text { населення, } \\
\text { млн. чол. }\end{array}$ & $\begin{array}{c}\text { Парк легкових } \\
\text { автомобілів, } \\
\text { млн. од. }\end{array}$ & $\begin{array}{c}\text { Кількість } \\
\text { автомобілів } \\
\text { на 1000 чол. } \\
\text { населення, } \\
\text { штук }\end{array}$ \\
\hline США & 315,31 & 202,23 & 641 \\
\hline Німеччина & 81,89 & 45,56 & 532 \\
\hline Польща & 38,82 & 18,17 & 474 \\
\hline Росія & 143,0 & 37,22 & 260 \\
\hline Україна & 44,94 & 8,04 & 179 \\
\hline \multicolumn{5}{|c|}{ Україна у відсотках до } \\
\hline США & 14,2 & 3,9 & 27,9 \\
\hline Німеччина & 54,8 & 17,6 & 33,6 \\
\hline Польща & 115,7 & 44,2 & 37,7 \\
\hline Росія & 31,4 & 21,6 & 68,8 \\
\hline
\end{tabular}

- Розраховано за даними: [1,2].

3 аналізу даних табл. 1 слідує, що вітчизняний автомобільний парк досить недостатньо розвинутий. Навіть за кількістю ми значно відстаємо. Але, якщо проаналізувати структуру легкових машин та потужність їхніх двигунів, то стане зрозумілим реальне відставання України від цивілізованих країн за рівнем автомобілезабезпечення. 3 автомобілебудуванням пов'язаний науково-технічний прогрес. Автомобільний завод, як правило, налічує сотні, а то і тисячі підприємств, які виробляють основні складові частини та допоміжні матеріали, які входять у десятки галузей економіки. За семантикою автомобільна галузь є однією 3 інноваційних, адже постійне оновлення технологій тут $є$ одним 3 пріоритетів конкуренції на внутрішньому та зовнішньому ринках. Доцільно нагадати, що автомобільна промисловість $є$ однією 3 структуроутворюючих галузей для переважної частки країн. Це 
Економічні науки: збірник наукових праџь Луцького національного технічного університету. - Серія "Регіональна економіка". - Випуск 15 (59). - Редкол.: відп. ред. д.е.н., професор Л.Л. Ковальська. - Луцьк: ІВВ Луиького НТУ, 2018. - 292 с.

є галузь, на яку працюють десятки суміжних та додаткових галузей, сотні і тисячі підприємств різних форм власності та господарювання.

Головним завданням розвитку транспортно-дорожнього комплексу України на середньостроковий період та до 2020 р. $є$ визначення шляхів розв'язання проблем подальшого розвитку транспортної галузі, зростання попиту на транспортні послуги, активізації процесів інтеграції транспортно-дорожнього комплексу України до європейської та світової транспортних систем. Для сучасного економічного стану України характерним $\epsilon$ підвищення ролі транспорту, який забезпечує життєдіяльність населення, функціонування i розвиток економіки держави, збереження ii обороноздатності, можливість досягнення зовнішньоекономічних цілей країни.

Для автомобілебудівної промисловості важливою $є$ інвестиційна та інноваційна діяльність. За своєю сутністю автомобіль $\epsilon$ інноваційним досягненням, у якому сконцентровані досягнення вчених 3 різних галузей та країн. В Україні інноваційна дільність у галузі автомобільного транспорту регулюється Законом України «Про інноваційну діяльність» [4]. Крім того, важливим є Закон України "Про транспорт", яким визначено, що до складу автомобільного транспорту входять підприємства автомобільного транспорту, які здійснюють перевезення пасажирів, вантажів, багажу, пошти, авторемонтні і шиноремонтні підприємства, рухомий склад автомобільного транспорту, транспортно-експедиційні підприємства, а також автовокзали i автостанції, навчальні заклади, ремонтно-будівельні організації та соціально-побутові заклади, інші підприємства, установи та організації незалежно від форм власності, що забезпечують роботу автомобільного транспорту. Даний закон регулює відносини між автомобільними перевізниками, замовниками транспортних послуг, органами виконавчої влади та органами місцевого самоврядування, пасажирами, власниками транспортних засобів, а також їх відносини 3 юридичними та фізичними особами-суб'єктами підприємницької діяльності, які 
Економічні науки: збірник наукових праиь Луиького національного технічного університету. - Серія "Регіональна економіка". - Випуск 15 (59). - Редкол.: відп. ред. д.е.н., професор Л.Л. Ковальська. - Луцьк: ІВВ Луцького НТУ, 2018. - 292 с.

забезпечують діяльність автомобільного транспорту та безпеку перевезень.

Розвиток автомобільного транспорту за погодженням 3 іншими центральними органами виконавчої влади відбувається відповідно до програми розвитку і вдосконалення транспорту, яку готує центральний орган виконавчої влади, що забезпечує формування та реалізує державну політику у сфері транспорту, i затверджує Кабінет Міністрів України. Закон України "Про утилізацію транспортних засобів" визначає правові, організаційні та економічні засади діяльності, пов'язаної 3 утилізацією транспортних засобів на території України з метою забезпечення екологічної безпеки, охорони навколишнього природного середовища, життя та здоров'я громадян.

Автомобілебудівна промисловість в Україні переживає не кращі часи. Нині в автомобілебудівну галузь в основному входять автоскладальні підприємства. Причина має економічне підгрунтя i полягає в тому, що вітчизняне виробництво автомобілів за повним циклом залишається менш вигідним у порівнянні із збиранням. В результаті чого різко скоротився асортимент автомобілів 3 повним циклом виробництва в Україні. При цьому виробничі потужності в автомобілебудівній галузі використовуються в середньому лише на 20-25 відсотків. В той же час маємо практичну відсутність обігових коштів, проблеми із взаємозаліками та проблеми зі збутом готової продукції.

Нині значна частка основних фондів автомобілебудівних підприємств десь на рівні 50-60 відсотків $\epsilon$ морально застарілими, а 60-70 відсотків є і фізично застарілими. В таких несприятливих умовах автомобілебудівні підприємства змушені оптимізувати витрати за рахунок скорочення чисельності працюючого персоналу. Але, як свідчить світовий досвід, для забезпечення належного попиту на продукцію підприємствам необхідно впроваджувати інноваційну модель розвитку, використовуючи новітні науковомісткі технології. Такий підхід потребує вливання значних інвестиційних коштів, які б 
Економічні науки: збірник наукових праџь Луцького національного технічного університету. - Серія "Регіональна економіка". - Випуск 15 (59). - Редкол.: відп. ред. д.е.н., професор Л.Л. Ковальська. - Луцьк: ІВВ Луиького НТУ, 2018. - 292 с.

дозволили модернізувати корінним чином підприємства вітчизняного автопрому.

Важливою проблемою управління галузями національної економіки будь-якої держави $\epsilon$ визначення такого типу розвитку, який буде стимулом для стрімкого економічного зростання спочатку ключових базових галузей, а далі і всієї економіки. Збільшення грошових надходжень від іноземних інвесторів є позитивним явищем для економічної розбудови вітчизняної автомобільної галузі. Здійснення інвестиційної діяльності в державі є фактором її інвестиційної та економічної безпеки. На сьогоднішньому етапі розвитку для вітчизняної автомобільної галузі $\epsilon$ вкрай важливим питання, щодо збільшення частки залучення прямих іноземних інвестицій, адже на відніму від кредитів і позик, інвестиції не заганяють державу в боргову яму. Причому доцільно відмітити інноваційну спрямованість залучених інвестицій. В умовах трансформаційних змін вітчизняної автомобілебудівної галузі постає необхідність формування нових підходів до визначення іiі інвестиційної привабливості. Поки що не існує єдиного підходу до визначення інвестиційної привабливості національної економіки. Так, при аналізі інвестиційної привабливості вітчизняної автомобільної галузі доцільно проаналізувати, крім власне економічних показників розвитку даної галузі, також такі макроекономічні показники розвитку держави, як дефіцит державного бюджету, обслуговування і погашення державного боргу, обсяг валового внутрішнього продукту, обсяг експорту та імпорту товарів i послуг. Існує потреба в подальших дослідженнях щодо інвестиційної привабливості вітчизняного автомобілебудування. Доцільно спрямувати зусилля на розробку, на показники формування сприятливого інвестиційного поля держави в цілому.

Забезпечення конкурентних переваг автомобілебудівного підприємства має будуватися не лише на реагуванні на динамічні якісно нові зміни зовнішнього середовища, але і на запобіжні. Вони полягають у впровадженні у виробництво 
Економічні науки: збірник наукових праџь Луцького національного технічного університету. - Серія "Регіональна економіка". - Випуск 15 (59). - Редкол.: відп. ред. д.е.н., професор Л.Л. Ковальська. - Луцьк: ІВВ Луцького НТУ, 2018. - 292 с.

високотехнологічних виробів, подальшим технічним i технологічним насиченням готової продукції.

В сучасних умовах $є$ потреба в корінній модернізації автомобілебудівних заводів, в їх технічному переоснащенні, тобто їх потрібно поставити на інноваційну модель розвитку. В сучасних умовах, ніде правди діти, це мають бути імпортні нові технології. Лише за їх рахунок вітчизняна автомобільна продукція буде конкурентоспроможною у порівнянні 3 закордонними аналогами. Але паралельно потрібно розвивати далі вітчизняну науку 3 метою розробки вітчизняних нових науковомістких технологій. Наразі в Україні спостерігається тенденція недостатнього фінансування інноваційної діяльності, що зводить інноваційну діяльність до вдосконалення вже існуючих прототипів. До основних чинників, що стримують інноваційну діяльність відносять недолік власних фінансових коштів і високу вартість нововведень [6].

Перехід автомобільної галузі України на інноваційну модель розвитку, передусім, залежить від державної підтримки. Наразі представлений проект державної цільової економічної програми розвитку автомобільної промисловості та регулювання ринку автомобілів на період до 2015 року. Основними завданнями програми є: зростання темпів випуску наукоємної продукції високого технологічного рівня i виробництва нової конкурентоздатної продукції.

Таким чином, сучасна стратегія державної підтримки промислової політики України в автомобільній галузі повинна орієнтуватися на зростання темпів наукомісткої продукції високого технологічного рівня i впровадження високотехнологічних інновацій у розбудову цієї галузі.

Здійснення стратегії інноваційного розвитку можливе лише через створення сприятливих умов для формування, використання та розвитку інтелектуального потенціалу як на рівні окремої людини, так і підприємства, регіону, суспільства в цілому. Основою такої стратегії має бути створення правових, організаційних та економічних умов для підвищення рівня використання та розвитку інтелектуального та інноваційного 
Економічні науки: збірник наукових праџь Луцького національного технічного університету. - Серія "Регіональна економіка". - Випуск 15 (59). - Редкол.: відп. ред. д.е.н., професор Л.Л. Ковальська. - Луцьк: ІВВ Луцького НТУ, 2018. - 292 с.

потенціалу. Для вирішення цих проблем необхідно удосконалити систему державного управління у галузі автомобільного транспорту та підвищити якість надання послуг 3 перевезення пасажирів та вантажів.

У формуванні інноваційного потенціалу підприємства у сучасному світі зростає роль інтелектуального капіталу, особливо це стосується автомобілебудівних підприємств. Створення інтелектуального капіталу проходить фази формування чіткої структури нематеріальних активів, що грунтується на відповідних облікових даних; інвестування в розвиток людського капіталу (нарощування компетентності або управління знаннями); систематична трансформація людського капіталу в структурний, що забезпечує набагато більший i стабільний потенціал прибутку для організації; вливання структурного капіталу із зовнішніх джерел, що забезпечує турбоефект у максимізації інтелектуального капіталу, який пов'язаний із спільним використанням та орендою нематеріального і структурного капіталу. В компаніях-лідерах, орієнтованих на знання, як правило, ринкова вартість перевищує балансову більш ніж в 2 рази. В Україні ситуація 3 використанням інтелектуального потенціалу $\epsilon$ на даний час незадовільною внаслідок його неефективного використання. Так, з 1000 патентів, зареєстрованих в Україні, у виробництві використовується лише 5-6 відсотків. Для порівняння: у Фінляндії реалізується близько 30 відсотків, а у розвинутих подекуди навіть до 80 відсотків. При появі значної кількості інновацій, як показує досвід розвинутих країн, буде виникати потреба щодо управління потоком інновацій.

Висновки. У вітчизняних автомобілебудівних підприємствах має місце недооцінка ролі інтелектуального капіталу у процесі забезпечення їх розвитку, що має наслідки втрачання можливостей власного розвитку. В цілому, роль інтелектуального капіталу в інноваційній діяльності вітчизняних підприємств є істотно заниженою.

Отже, виникає потреба в адаптації чинного національного законодавства у галузі автомобільного транспорту до 
Економічні науки: збірник наукових праџь Луцького національного технічного університету. - Серія "Регіональна економіка". - Випуск 15 (59). - Редкол.: відп. ред. д.е.н., професор Л.Л. Ковальська. - Луцьк: ІВВ Луцького НТУ, 2018. - 292 с.

європейського, зокрема щодо управління перевезеннями, регулювання ринку транспортних послуг, доступу до ринку послуг 3 перевезення пасажирів та вантажів, підвищення конкурентоспроможності автомобільних перевізників, забезпечення безпеки руху, здійснення транзитних перевезень, прикордонного контролю, визначення вимог до колісних транспортних засобів, транспортної статистики, екологічних та соціальних вимог. Крім того, потрібно інтегрувати вітчизняну систему автомобільного транспорту до європейської через об'єднання 3 трансєвропейською транспортною мережею відповідно до Європейської політики сусідства.

1. Асоціація автовиробників України. Статистика. [Електронний pecypc].- Режим доступу: http://ukrautoprom.com.ua/uk/statistika.

2. Автомобілебудування України [Електронний ресурс]. Режим доступу: http://ukrexport.gov.ua/ukr/prom/ukr/29.html.

3. Божко В.П. Аналіз сучасного стану машинобудівної галузі України / В.П. Божко, І.О. Кащеєва // Бізнес Інформ. - 2013 - Вип. 4 - С. 190-194.

4. Закон України «Про інноваційну діяльність»: [Електронний ресурс]. - Режим доступу: http: //zakon.rada.gov.ua/cgi-bin/ laws/main.cgi?nreg=3715-17.

5. Данилишин Б.М. Машинобудування в Україні: тенденції, проблеми, перспективи. - Ніжин: Аспект-Поліграф, 2007. - 308 с.

6. Зима А.О., Біркентале В.В. Інноваційна діяльність як основа підвищення конкурентоспроможності підприємств та регіонів // Вісник Донецького національного університету, Серія В: Економіка і право. Випуск I - Донецьк, 2009. - 250 с.

7. Концепція розвитку автомобільної промисловості та регулювання ринку автомобілів у період до 2015 року [Електронний ресурс]. Режим доступу: http://www.gdo.kiev.ua/files/db.php?god=2006\&st=2241.

8. Матковський С.О. Інноваційна активність підприємств Львова в 2010 році: [Електронний ресурс] // Головне управління статистики у Львівській області. - 2011. - № 59. - Режим доступу: http://stat.lviv.ua/ukr/si/press/2011/r040411_59.pdf.

9. Проблеми управління інноваційним підприємництвом екологічного спрямування: Монографія / За заг. ред. О.В. Прокопенко. - Суми: ВТД «Університетська книга», 2007. - 512 с. Випуск 10. - 2016. Миколаївський національний університет імені В.О. Сухомлинського.

10. Семирак О.С. Формування масиву ідентифікаційних характеристик автомобілебудування в Україні / О.С. Семирак // Вісник Дніпропетровського національного університету. - 2014. - Т.22, № 1011. - С. 47-54. 
Економічні науки: збірник наукових праць Луиького національного технічного університету. - Серія "Регіональна економіка". - Випуск 15 (59). - Редкол.: відп. ред. д.е.н., професор Л.Л. Ковальська. - Луцьк: ІВВ Луиького НТУ, 2018. - 292 с.

11. Чорнобровкіна С.В. Сучасний стан проблеми металургійної та машинобудівної промисловості України / С.В. Чорнобровкіна // Вісник НТУ «ХПІ»-2015. - Вип. 26. - С. 62-68.

12. Шеховцова І.А., Полонська Є.С. Інноваційний розвиток автомобільної промисловості України [Електронний ресурс]. Режим доступу: http://www.nbuv.gov.ua/e-journals/PSPE/2009_4/Shehovcova_409.htm. 